\title{
Research on Financial Elasticity Accounting Conservatism Modeling Based on Suitability Test
}

\author{
Li Yue \\ Guangzhou Huashang Vocational College, Guangzhou511300, China. \\ 15989280129@126.com
}

Keywords: fitness test; financial elasticity; accounting; conservatism modeling

Abstract: Accounting conservatism has a decision effect on financial elasticity, aiming to improve the conservatism of financial elasticity accounting, a modeling method of financial flexibility accounting conservatism based on fitness test is proposed. The relationship between financial report conservatism and enterprise debt is studied, the information symmetry by combining the relevance of equity market and debt market is analyzed, and accounting conservatism by controlling accrual profits is measured. On the basis of the measurement model, the paper analyzes the operational accrual items on the basis of the measurement model, uses panel data to analyze the financial elasticity accounting conservatism model, and obtains the regression residual error. In this paper, a basic model of target financial leverage prediction is established. Taking into account that there may be multiple collinearity among the explanatory variables, the descriptive statistical analysis is carried out by using VIF test and combining fitness test and F test method to analyze financial elasticity accounting conservatism. The results of empirical analysis show that the model has good robustness in modeling accounting elasticity and non-efficiency investment. Enterprises can look for a long-term mechanism to improve investment efficiency and improve profit level from the level of financial resources allocation.

\section{Introduction}

After Watts put forward the viewpoint of accounting conservatism, the research on the economic consequence of accounting conservatism increases year by year. Among them, the influence of accounting conservatism on enterprise debt contract has been paid more and more attention. For example, Watts believes that sound accounting can enhance the effectiveness of debt contracts by reconciling the interests between debtors and creditors ${ }^{[1]}$. LaFond and Watts, and LaFond and Roychowdhury by studying financial reporting soundness and corporate debt levels, debt costs, And the relationship between the terms of the debt contract, it is proved by empirical data that accounting conservatism in equity and debt markets can alleviate the contradiction between the interests of both parties caused by asymmetric information. Ball further finds that the development of a regional debt market is positively related to the degree of accounting conservatism. Along the lines of the above research, the signaling mechanism of accounting conservatism reduces creditors' 
expectation of default risk, and the enhancement of accounting conservatism makes debt capital and equity capital providers more willing to increase their support for enterprise financing ${ }^{[2]}$. Make the enterprise obtain more favorable debt financing condition, thus reduce the financing constraint of the enterprise, improve its financial elasticity.

Financial elasticity is the result of internal and external factors, so it is difficult to describe the relationship between accounting conservatism and financial elasticity through specific indicators. Therefore, it is difficult to study the relationship between accounting conservatism and financial elasticity directly. Management is the choice of accounting policy, which can have a reasonable expectation on the future financial elasticity of the enterprise according to the degree of prudent policy choice, and this expectation will have an important impact on its financial decision. Therefore, the financial elasticity of enterprises can be deduced by observing the financial decision results such as cash holding, cash / cash flow sensitivity, investment / cash flow sensitivity and so on, and then the relationship between accounting conservatism and financial elasticity can be clarified. In this paper, we find that the higher the accounting conservatism, the more the cash holdings, which indicates that accounting conservatism reduces the financial elasticity of enterprises and makes the financial decisions of enterprises tend to be conservative. A stronger precautionary incentive to hold cash; the higher the cash / cash flow sensitivity of an enterprise with higher accounting conservatism, which indicates that accounting conservatism reduces the financial elasticity of an enterprise, Make the enterprise more rely on operating cash flow to accumulate the required funds. Accounting conservatism is measured by controlling accrual profits ${ }^{[3]}$. On the basis of the measurement model, the paper analyzes the operational accrual items on the basis of the measurement model, and uses panel data to analyze the financial elasticity accounting conservatism model, and obtains the regression residual error. In this paper, a basic model of target financial leverage prediction is established. Considering that there may be multiple collinearity among the explanatory variables, combining the fitness test and $\mathrm{F}$ test method, the financial elasticity accounting conservatism is analyzed, and finally, the empirical analysis is carried out. This paper shows the superiority of the design model in improving the financial flexibility accounting conservatism modeling.

\section{Analysis of constraint variables between accounting conservatism and enterprise financial elasticity}

\subsection{Theoretical analysis of financial elasticity and accounting conservatism}

The classical capital structure theory, such as static trade-off theory and financing priority theory, holds that moderate debt is beneficial to the promotion of enterprise value. In theory, companies should raise investment funds through internal financing, then debt financing, and then issue stocks. However, in reality, many enterprises do not conform to theoretical predictions. They tend to use debt more conservatively and hold higher cash positions. Financial elasticity means that enterprises take timely action to change the amount and time distribution of cash inflows. Ability to respond to unexpected cash requirements and seize unexpected investment opportunities. In foreign countries, the research literature on financial elasticity is abundant, mainly on its relationship with expenditure policy, investment policy and,). From the existing literature, there are several problems: first, foreign scholars are rich in the study of financial elasticity, but less to combine it with non-efficient investment, while our scholars are quite rich in the study of non-efficient investment. Second, although a few domestic scholars based on the perspective of financial elasticity to study inefficient investment behavior, but only a simple descriptive statistics, not in-depth research; third, The validity of financial elasticity index used by Chinese scholars is controversial. The relationship between business performance, etc ${ }^{[4]}$. 
The use of free cash flow for excessive investment is an important means for managers to make private profits. Financial elasticity is an important symbol of an enterprise's ability to adapt to the external environment and the degree of financial relaxation ${ }^{[5]}$. The financial elasticity of a company not only reflects the characteristics of the company's size, but also reflects the company's capital structure. Liquidity and investment-related strategic decisions. In order to better finance future investments, companies will tend to maintain a higher degree of financial slack, that is, high financial flexibility companies tend to rely on financial flexibility in their investment expenses. Based on the above analysis. Under the assumption of "perfect capital market", MM theory holds that investment depends on investment opportunities, and enterprises can always raise external funds at the same cost of internal capital to meet the needs of investment. Due to the imperfect capital market in reality, asymmetric information and agency problems lead to the difference between internal and external financing costs. The financing constraint hypothesis analyzes how the prior information asymmetry affects the financing behavior of enterprises and leads to the emergence of inefficient investment ${ }^{[6]}$.

\subsection{Financial decision model of accounting conservatism}

Financial elasticity can alleviate the impact of financing constraints, enhance the ability of enterprises to seize investment opportunities and deal with unexpected events. When uncertainty of investment opportunities and future returns is reduced, enterprises with financial flexibility have sufficient endogenous funds. External funds are easy to obtain and can grasp the ability of investment expansion. For the financial stability of the $K \subset I$, $\left(u, u_{t}\right) \in C_{t}\left(K, \dot{H}_{x}^{s_{c}} \times \dot{H}_{x}^{s_{c}-1}\right), u \in L_{t, x}^{d+1}\left(K \times I R^{d}\right)$, enterprise market value of the investment project stability functional formula is:

$$
u(t)=w(t)\left(u_{0}, u_{1}\right)+\int_{0}^{t} \frac{\sin \left(\left(t-t^{\prime}\right)|\nabla|\right)}{|\nabla|} F\left(u\left(t^{\prime}\right)\right) d t^{\prime}
$$

Where, $F(u)=|u|^{4} u$. The sensitivity of investment to cash flow is lower than that of inelastic enterprises. Let $x^{*}$ be a limit point in the solution of $\left\{x_{k}\right\}$. Firms with financial flexibility are less affected by the imperfection of capital market, and their investment ability will not be due to information asymmetry. The agency cost problem is more damaged, so a basic model of target financial leverage prediction is established. The model is described as:

$$
\boldsymbol{J}=\sum_{k=0}^{\infty}\left[\mathbf{z}^{\mathrm{T}}(k) \mathbf{z}(k)-\gamma^{2} \boldsymbol{w}^{\mathrm{T}}(k) \boldsymbol{w}(k)\right]
$$

By constructing a model of expected investment expenditure, we can get that the homogeneous term converges to:

$$
\boldsymbol{J} \leq \boldsymbol{\Phi}_{2}(k) U \Phi_{2}^{\mathrm{T}}(k)
$$

Model variables for estimating the normal investment level of an enterprise:

$$
U=\left[\begin{array}{ccc}
\bar{A}^{T} P \bar{A}-P+K^{T} R K+C^{T} C & \bar{A}^{T} P \bar{B}+C^{T} D & \bar{A}^{T} P F_{1}+C^{T} F_{2} \\
\bar{B}^{T} P \bar{A}+D^{T} C & \bar{B}^{T} P \bar{B}-R+D^{T} D & \bar{B}^{T} P F_{1}+D^{T} F_{2} \\
F_{1}^{T} P \bar{A}+F_{2}^{T} C & F_{1}^{T} P \bar{B}+F_{2}^{T} D & F_{1}^{T} P F_{1}+F_{2}^{T} F_{2}-\gamma^{2} I
\end{array}\right]
$$

If the regression residuals are greater than zero, the value of the regression residuals is overinvestment, which is represented by the symbol Overinv ${ }^{[7]}$, and the regression residuals are less than zero, and the values of the regression residuals are underinvested. The integral term for the 
asymptotic expansion of nonlinear singularly perturbed equations on $I R^{d}$ is:

$$
\hat{f}(\xi)=(2 \pi)^{-d / 2} \int_{I R^{d}} \mathrm{e}^{-\mathrm{ix} \cdot \xi} f(x) d x
$$

For the residual liability capacity, this paper also uses the reverse number measurement of the residual error of the model to construct the variable model of the impairment loss model of financial assets $^{[8]}$.

\section{Modeling optimization of financial elasticity accounting conservatism}

Based on the information symmetry analysis of the relationship between equity market and debt market, accounting conservatism is measured by controlling accrual profits. Based on the measurement model, this paper analyzes the operational accrual items on the basis of the measurement model, and makes regression analysis on the financial elasticity accounting conservatism model by using panel data. This paper proposes a new method based on fitness test. The financial elasticity accounting analysis model, carries on the descriptive statistical analysis, according to the company property right nature, the listing age is a constraint variable, and the regular items of financial elastic accounting constraints are expressed as follows:

$$
\dot{H}_{x}^{s}\left(I R^{d}\right):=\left\{f:\|f\|_{\dot{H}_{x}^{s}\left(I R^{d}\right)}:=\left.\|\| \nabla\right|^{s} f\left\|_{L_{x}^{2}\left(I R^{d}\right)}=\left|\left\|\left.\xi\right|^{s} \hat{f}\right\|_{L_{\xi}^{2}\left(R^{d}\right)}<\infty\right\}\right.\right.
$$

The mean test of inefficiency investment of different enterprises in financial elasticity is:

$$
\|f\|_{L_{L_{L}^{q}}^{L_{x}\left(I \times I R^{d}\right)}}=\left(\int_{I}\left(\int_{I R}|f(t, x)|^{r} d x\right)^{q / r} d t\right)^{1 / q}
$$

Considering that there may be multiple co-linearity among the explanatory variables, the stronger the firm's financial reporting stability is, the higher the financial elasticity is. In this paper, the VIF test is carried out, and the test process of cash accumulation in the current cash flow is described as follows:

$$
\begin{aligned}
2 \xi^{T}(t) W\left[x\left(t-d_{1}(t)\right)-x\left(t-h_{1}\right)-\int_{t-h_{1}}^{t-d_{1}(t)} \dot{x}(s) d s\right] & =0 \\
2 \xi^{T}(t) K\left[x(t)-x\left(t-d_{1}(t)\right)-\int_{t-d_{1}(t)}^{t} \dot{x}(s) d s\right] & =0
\end{aligned}
$$

Deferred revenue recognition and early expense recognition result in the minimization of cumulative profits, resulting in higher liability value and lower asset value, resulting in accounting conservatism modeling output:

$$
\left\||\nabla|^{s}(f g)\right\|_{L_{x}^{p^{2}}} \leq\left|\left\|\left.\nabla\right|^{s} f\right\|_{L_{x}^{p_{1}}}\|g\|_{L_{x}^{p_{2}}}+\|f\|_{L_{x}^{p_{3}}}\left\|\left.\nabla\right|^{s} g\right\|_{L_{x}^{p_{4}}}\right.
$$

In order to test the accounting conservatism and the sensitivity of investment / cash flow, and add the accounting conservatism variable and the cross item between accounting conservatism and cash flow, the model of financial elasticity accounting conservatism can be realized ${ }^{[9]}$.

\section{Empirical analysis and test}

This paper uses the above model to select the sample company's data from 2013 to 2017 as the research sample, tests the accounting conservatism of the financial data, selects the cash holdings and the residual liability ability as the proxy variable of the financial elasticity. A basic model of target financial leverage prediction is established. The sample number of FF, AFF and NFF is 292, 786 and 410, respectively. The results of descriptive statistical analysis of financial elasticity 
accounting analysis are shown in Table 1.

As can be seen from table 1, the average change of cash flow of enterprise holdings is 0.123 , indicating that the sample companies have increased their cash holdings in recent years. To verify this conclusion, we test the relationship between accounting conservatism and cash holdings, and obtain the results shown in figure 1.

Table 1. Descriptive statistical analysis results

\begin{tabular}{ccccc}
\hline Year & LEV & CASH & CFO & COV \\
\hline 2010 & 0.521 & 0.643 & 0.765 & 0.765 \\
2011 & 0.435 & 0.564 & 0.533 & 0.345 \\
2012 & 0.443 & 0.557 & 0.286 & 0.676 \\
2013 & 0.643 & 0.324 & 0.546 & 0.676 \\
2014 & 0.656 & 0.675 & 0.654 & 0.423 \\
2015 & 0.454 & 0.565 & 0.646 & 0.676 \\
2016 & 0.654 & 0.354 & 0.378 & 0.653 \\
2017 & 0.565 & 0.664 & 0.435 & 0.676 \\
\hline
\end{tabular}

Figure 1 shows that there is a positive correlation between accounting conservatism and cash holdings. All four models have passed the confidence test, and model 3 and model 4 are significant at the level of $1 \%$ confidence. The relationship between accounting conservatism and enterprise investment scale, we use the above model to test conservatism, and the result is shown in figure 2 .

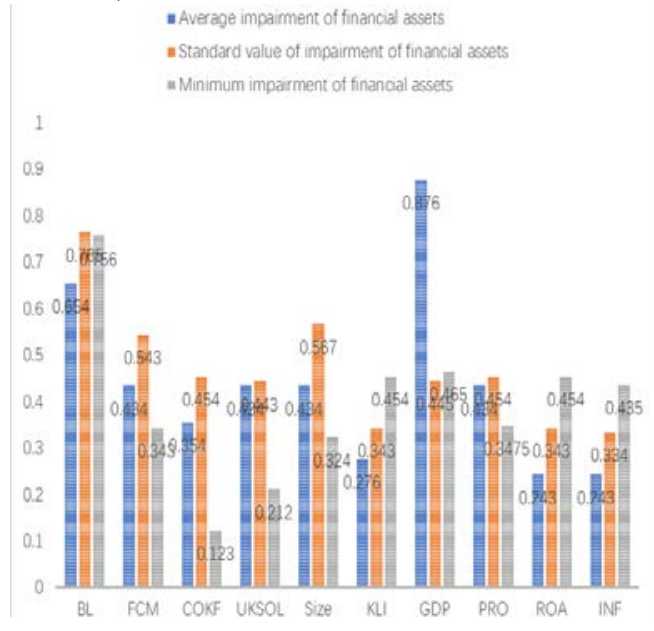

Fig. 1 Confidence test results of the relationship between accounting conservatism and cash holdings

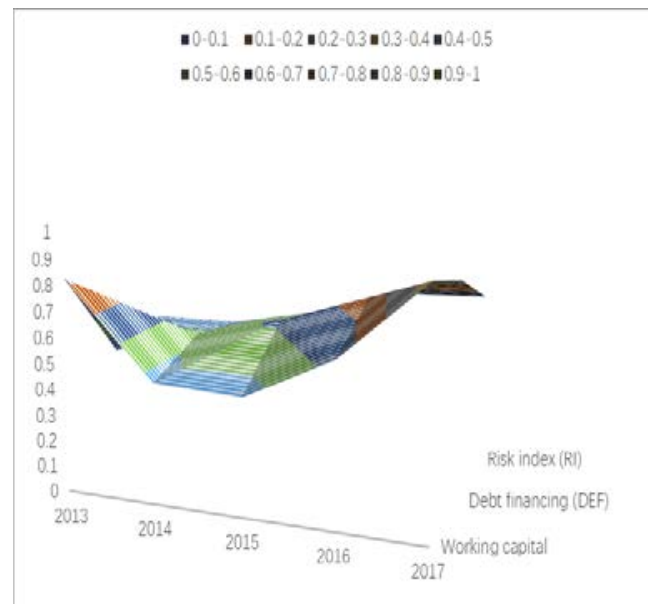

Fig. 2 Results of conservatism test of financial elasticity accounting

Figure 2 shows that accounting conservatism has a negative correlation with the scale of enterprise investment under the four models, and is significant at the level of $1 \%$ confidence, indicating that accounting conservatism reduces the sensitivity of investment / cash flow. Has restrained the excessive investment impulse of the enterprise, Improved and financial flexibility accounting conservatism.

\section{Conclusions}

In this paper, a financial flexibility accounting conservatism modeling method based on fitness test is proposed. This paper studies the relationship between financial report conservatism and 
enterprise debt, analyzes the information symmetry by combining the relevance of equity market and debt market, and measures accounting conservatism by controlling accrual profits. This paper focuses on the impact of accounting conservatism on enterprise financial decision-making, the relationship between accounting conservatism and financial elasticity, the influence of accounting conservatism on enterprise cash holding is studied. After the increase of accounting conservatism variable, the coefficient between investment scale and enterprise cash flow is obviously improved, and accounting conservatism is multiplied by cash flow. There is also a significant positive correlation, which reflects that the sensitivity between investment and cash flow increases after the firm chooses prudent accounting policies, and the firm investment is more dependent on the internal cash flow.

\section{References}

[1] ZHAO Xiaolin, WU Yipeng, HUANG Huiying,et al. New generation of migrant workers housing purchasing power and the housing sales to inventory constraints relationship model -- Taking Zengcheng area as an example[J]. Management Engineer, 2017,22(1):8-13.

[2] YAN Lei,JIANGanyin,FENG Zhiku.Life Cycle Characteristics and Financing Matching Analysis on the lnvestment Value of SME of Technology Type [J]. Contemporary economic science,2016,(03):114-123.

[3] Huang X, Wang Z, Li Y, et al. Design of fuzzy state feedback controller for robust stabilization of uncertain fractional-order chaotic systems [J]. Journal of the Franklin Institute, 2015, 351(12): 5480-5493.

[4] XIONG He, GUO Youqiang, ZHU Honghao, WANG Shuo. Robust Nonnegative Matrix Factorization on Manifold via Projected Gradient Method [J]. Information and control, 2018, 47(2): 166-175.

[5] Wu Y, Shen B, Ling H. Visual tracking via online nonnegative matrix factorization [J]. IEEE Transactions on Circuits and Systems for Video Technology, 2014, 24(3):374-383.

[6] Ye M, Qian Y, Zhou J. Multitask sparse nonnegative matrix factorization for joint spectral-spatil hyperspectral imagery denoising [J]. IEEE Transactions on Geoscience and Remote Sensing, 2015, 53(5):2621-2639.

[7] Hu L R, Wu J G, Wang L. Application and method for linear projective non-negative matrix factorization[J]. Computer Science, 2013, 40(10):269-273.

[8] BAI Xuejie,SUN Hongyin,WANG Haifeng.M\&A Behaviors and Market Power ;An Analysis Based on Chinese A-share Enterprises[J].2016,(03):106-113.

[9] Wei Wei, Jiang Hai, Pang Sulin. Monetary policy, regulatory policy and bank credit behavior -- An Empirical Study Based on China's banking industry analysis (2002-2012) [J]. International finance research, 2016, 349 (5): 48-60. 